\title{
S110＼cjkstart骨密度分布を考慮した顎骨のモデル化と臨床問題への応用
}

\section{Modeling of Jaw Bone Considering Bone Density and Its Clinical Application}

\author{
○荒平 高章 (九大院) 正 東藤 貢（九大応研） 佐々木 匡理（九大歯学） \\ 竹之下 康治 (九大歯学) 正 新川 和夫（九大応研） \begin{abstract}
Mitsugu TODO, RIAM, Kyushu University
Masanori SASAKI, Faculty of Dental Science, Kyushu University

Yasuharu TAKENOSHITA, Faculty of Dental Science, Kyushu University

Kazuo ARAKAWA, RIAM, Kyushu University
\end{abstract} \\ Takaaki ARAHIRA, Graduate School, Kyushu University, Kasuga, Fukuoka
}

Keywords: Dental biomechanics, CT-image based modeling, Occlusion, Finite element analysis

\section{1. 緒 言}

現在, 複雑な生体組織の力学状態を近似的に高精度で把握 するために, X線 CT や MRI から得られる画像デー夕を用い て, 詳細な 3 次元 FEA モデルを作成し数値解析を行う技術 が開発され研究が進んでいる.歯科医学の分野においてこれ までに用いられた解析モデルは，下顎単独のモデルや顎骨の 部分的なモデル, およびそれらにインプラントを埋入したモ デルが多いのが現状である. しかし，実際に起こっているイ ンプラントのゆがみや破損といった問題は, 日常生活での食 事などに行う啮及締め行動から発生するものであり, その行 為は上顎と下顎の双方で行われているものである.したがっ て, 数值解析を行う際にも上・下顎の両方を有する顎骨モデ ルを構築し，実際の校合状態を再現することが望ましい。

そこで，本研究では，X 線 CT 画像を元に上・下顎骨の 3D-FEA モデルを作成し, そのモデルを用いて両側噛み締め 時の顎骨の力学状態を再現することを目的とした. 男性と女 性それぞれ 1 名のCT 画像を用いて 3D-FEA モデルを作成し, 同じ境界条件の下で顎骨の力学状態の差異について考察し た. また, 臨床的な応用問題として, 本研究では顎骨内に空 洞が形成される裹胞を取り上げ，3Dモデルの適用を試みた.

\section{2. 解析方法}

影骨モデルは, 生体構造解析ソフトウェア Mechanical Finder を用いて被験者（23 歳女性および 49 歳男性）の頭部 CT 画像から骨部分を抽出することで構筑した（Fig.1(a)）. CT のスライス間隔は女性が $1 \mathrm{~mm}$ 男性が $3 \mathrm{~mm}$ であり，それ ぞれのモデル作成に要した CT 画像はおよそ 100 枚と 50 枚 である，上顎については，鼻空の中央部より上部を省いてい る. 要素分割の一例として, female model の分割状態を Fig.1(b)に示す. 4 節点 4 面体要素を用いており, female model と male model の要素数はそれぞれ 880899 と 681478, 節点数 はそれぞれ 188230 と 145724 である. 顎骨モデルのヤング率 については, CT 值より骨密度を推定し, さらに骨密度から Keyak の理論を用いて決定しており, 要素ごとにヤング率を 設定した ${ }^{1)}$.

次に，輁胞を模したモデルを Fig.2に示す．襄胞は球状であ ると仮定し，下顎の左部前方に挿入した．通常，眥胞には液 が満たされるが，本モデルでは，ヤング率は $0.1 \mathrm{~Pa}$ ，ポアソ ン比は 0.3 とし，囊胞の直径は $8 \mathrm{~mm}$ に設定した。

本解析で用いた境界条件を Fig.3 に示す. 拘束条件として は, 上顎の上部を $\mathrm{Z}$ 方向に固定し, 関節部となる下顎の一端 は 3 軸方向の変位を全て固定し，もう一端はX，Z方向への 変位を固定している.すべての拘束点において，回転に拘束 は与えていない. 筋力としては, 咬筋 (M) , 側頭筋 (Ta, Tp),
内側翼突筋 $(\mathrm{Pm})$, 外側翼突筋 $(\mathrm{Pl})$ の作用を考慮して設定 した.

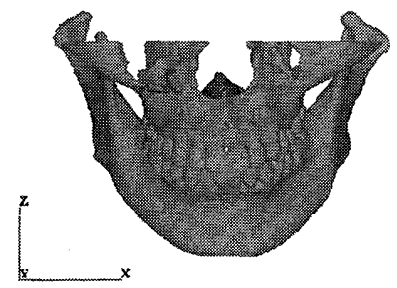

(a)Female model

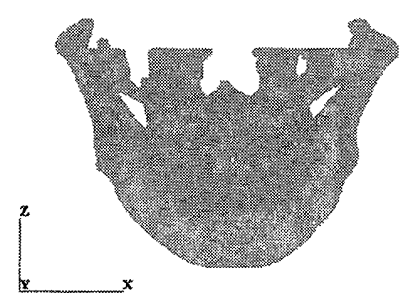

(b) Mesh image
Fig.1 CT-image based jow bone model.

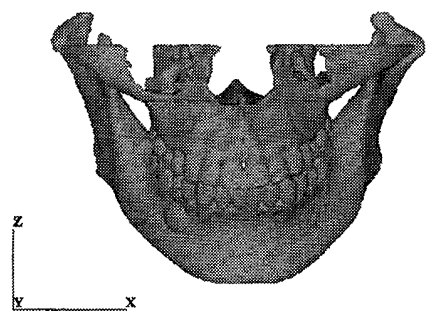

Fig. 2 Jawbone cyst model.

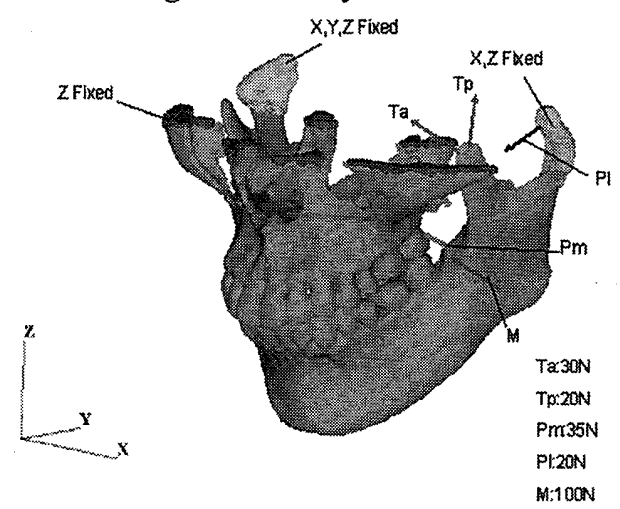

Fig.3 Boundary conditions.

\section{3. 結果と考察}

Fig.4に female model の顎骨中央で切断した面のヤング率 分布を示す. 表面の皮質骨に当たる部分が高ヤング率 (明る い部分）を，内部にある海綿骨部は低ヤング率（暗い部分） を示しており，実際の骨構造を反映したヤング率分布が再現 されている.また歯列はエナメル質を反映し, 高ヤング率を 示している.

Fig.5 にミーゼス相当応力分布を示す. 前面図で比較する と, female model の方がより高い応力が広範囲に分布してい

日本機械学会 (No. 08-53] 第 21 回バイオエンジニアリング講演論文集（'09-1.23〜24 札幌） 


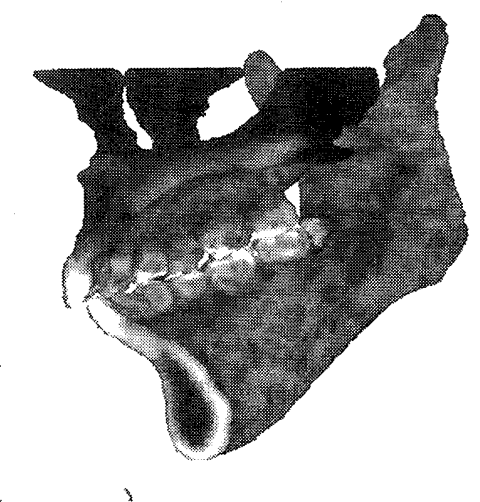

Fig.4 Distribution of Young's modulus.
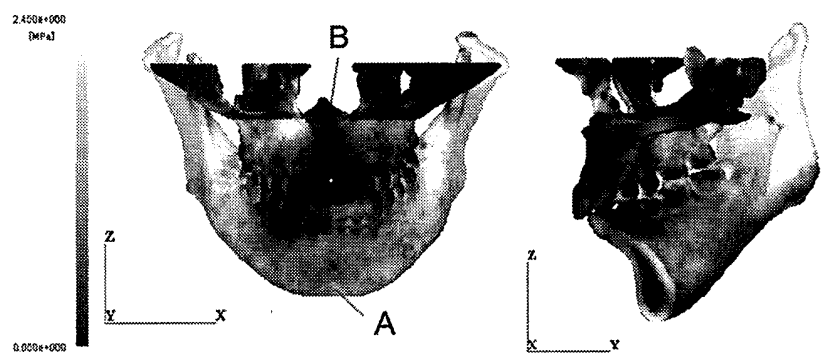

(a) Female model

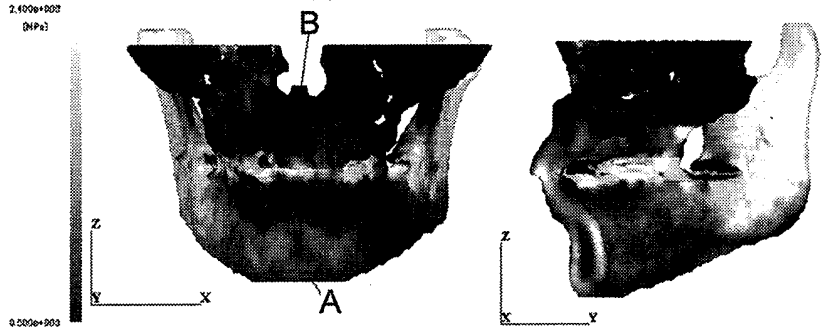

(b) Male model

Fig. 5 Distribution of the equivalent stress.

ることがわかる．また，顎骨中央部で切断した面より，皮質 骨で大きな忘力が発生している. Fig.5 に示す A 点と B 点で の相当応力を比較したグラフを Fig.6 に示す. A 点は䫟の先 端部，B 点は鼻空の下部先端をそれぞれ示している．このグ ラフから, female model の方が著しく高い忘力を受けている ことが分かる．皮質骨のヤング率が低く，顎骨量も少ない female model の方が male model よりも構造体としての剛性が 低いため, 同じ境界条件下で発生する応力は高い.

Fig.7 に，襄胞モデルでの相当応力分布を示す．図は襄胞 中央を通る面で切断した断面である. 霟胞モデルはヤング率 が極端に小さいため，それを取り曲んでいる皮質骨に高い応 カが作用している. Fig.8 に, 整胞モデルと正常モデルの相 当応力値を比較したグラフを示す. 襄胞モデルの方が高い応 力が生じていることが分かる，襄胞が進行すると，それを取 り囲む皮質骨が薄くなり，顎骨骨折の危険性が增大するが， 今回の囊胞モデルで囊胞を成長させることで, 顎骨骨折の予 測に利用できる可能性があることが示唆された。

\section{4. 結 言}

本研究では, 男女別にそれぞれ顎骨の3D モデルを作成し， 咬合状態を再現した境界条件で応力解析を行った. 骨密度分 布からヤング率分布を推定することで, 皮質骨と海綿骨のヤ ング率の差を再現することができ, 実生体構造に近い数值モ デルの構築が可能となった. 女性の方が皮質骨部のヤング率 が低いとともに骨量も少ないため構造体としての顎骨の剛
性は低く，男性よりは変形しやすく，より高い応力が発生す ることが定量的に確認できた. また, 臨床的な応用問題とし て襄胞という病的顎骨モデルを再現した. ヤング率の小さい

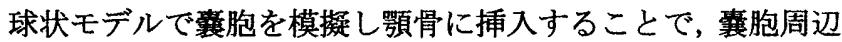
での高い忍力分布を再現することができた.

本研究で紹介した頽骨モデルの作成法を用いることで，患 者別の顎骨モデルの構築が可能となり, インプラント治療や 病的䝷骨の力学状態の解析など応用範囲は広い.

\section{参考文献}

1) J.H.Keyak, et al.,J. Biomech., 31, 1998, 125-133.

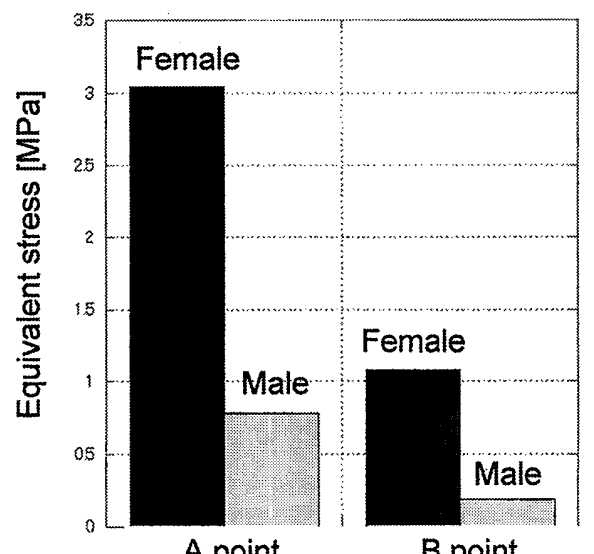

Fig.6 Comparison of the equivalent stress at two points.

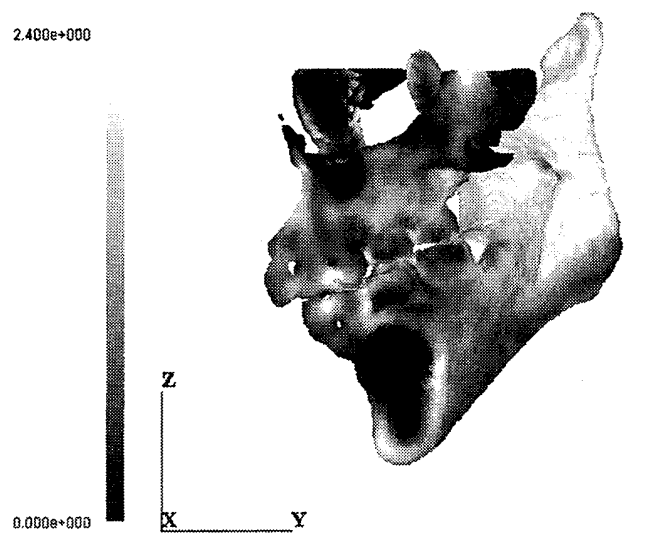

Fig.7 Distribution of the equivalent stress in cyst model.

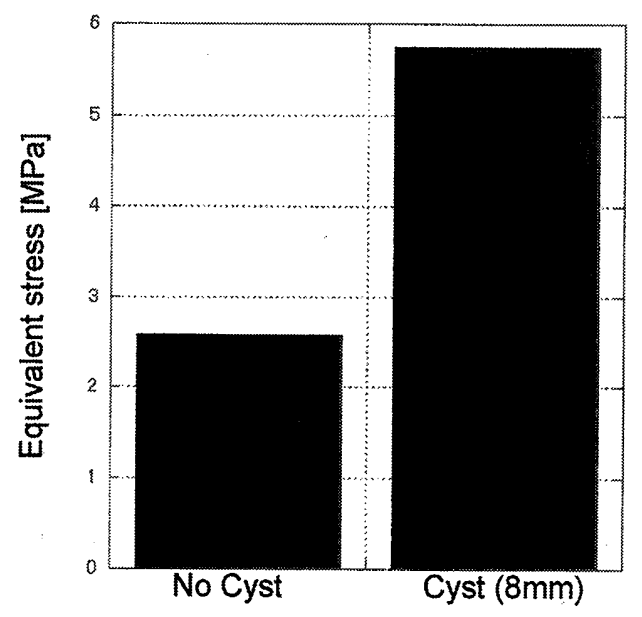

Fig. 8 Comparison of the equivalent stress. 